\title{
Gufa, a Unique Cultural Ritual- a Tale of a Forbidden Sun and a Girl
}

\author{
Pritisha Shrestha
}

\author{
Central Department of English, Tribhuvan University, Kathmandu, Nepal \\ email: prishafun@gmail.com
}

\begin{abstract}
Gufa, one of the traditional rituals, has been performed in Nepal since time immemorial by indigenous Newar people. In Gufa, a young girl who just had her first period is hidden in a sunless room for twelve consecutive days. This paper expounds the importance of ritual and its nexus with astronomy especially while interpreting how the daily motions of celestial objects have influenced the establishment and devolvement of a deep-rooted custom of Gufa.
\end{abstract}

Keywords. Cultural Astronomy, Sun, Nepal, Newar, Gufa, Ritual and Performance

\section{The ritual performance}

Gufa is part of the intangible cultural heritage of the Newars, an indigenous group of people in Nepal (Levy 1990, Nepali 2015). Gufa-also known as Surya Darshan or "sun's observation" - is a unique ritual. It is a puberty ceremony of a girl and her lifelong connection with the sun. During the twelve-day long ceremony, which starts when she gets her first period, she is prohibited from observing the sun and therefore stays in a room heavily curtailed to keep out the sun's rays. "Great care is taken to ensure that no ray of sunshine can enter the room since an explicit aim of the rite is to ensure that the girls are seen neither by men nor by the sun. The first three days are said to be especially dangerous because this is the ritually prescribed period of bleeding throughout the Hindu world" (Allen 1986, p. 14). The room becomes her own sanctuary where she learns her own body. From her female relatives, she learns the etiquette of being a woman and receives education about living in a society. The community celebrates her ritual as she is taken as a life bearer.

On the twelfth day, she is carefully brought out of the room and symbolically married to the sun, in a ritual. She is cleansed and dressed in new red attire, usually a sari, adorned with red bangles and golden jewelries to prepare for the long awaited reunion with the sun. She is cautiously taken to the rooftop of her house, with her head covered with a shawl. This step is believed to have removed all the remaining menarche potency in the girl. Her mother turns her to face the direction of the sun then removes the cover. Initially, she looks at the sun through its reflection in the basin of water put in front of her. Then she crosses her fingers together, in a unique fashion, and takes a glimpse of the sun by peeking through her fingers. After this point, her priest instructs her to sit on the floor where an array of worshipping items are placed, at the center of which is the image or an idol of sun itself. She pours a purifying liquid onto the image of the sun (ibid., p. 117) and she is ceremoniously and symbolically married to the sun. The logic behind the union after a pure restriction is to protect her sensitive young body and to ward off any harm to her reproductive parts from the sun's rays.

The French philosopher Van Gennep (2011) marks three distinct stages in ritual performances of coming of age: (a) separation, (b) liminal period, and (c) re-assimilation. 
At the onset of the ceremony, the Gufa girl is separated from her formerly possessed social status. Then, in the liminal phase, she gets a new identity of someone who is performing the ritual. Her former status from pre-ritual phase no longer holds and she has yet to gain her new identity from the ritual. When she completes her ritual, she is once again reintroduced into society with a new set of responsibilities and a new status. Her re-assimilation is marked at a grand feast where both male and female members of her community join to commemorate the event.

\section{The cosmic connection}

Although the sun is seen as the cosmic energy that energizes and revitalizes lives on earth, during menarche it is stringently forbidden to the Gufa girl. According to old Hindu scriptures, namely Vedas and Ayurveda, there is a constant build-up of energy in a woman's body in the days prior to her period, as the body is geared towards becoming pregnant. When there is no pregnancy, menstruation kicks off, releasing all the energy downward, and during this time, a woman is susceptible to absorb any energy floating in her surrounding environment. Maya Tiwari, an Ayurveda teacher, describes the innate psychology and collective consciousness that there is of cosmic memory of food. This memory, she writes, "[which] is derived only from plant life according to the Vedas ... is a rising energy flowing up from the earth towards the sun and the sky". On the contrary, there is a downward flow of energy during the period in which bodily air is pulled down from the body by the magnetic forces of the earth (Tiwari (2011), p. 67).

In many cultures the sun is revered as a male god. Dr. Tejeswar Babu Gonga, a culture expert and the president of the Nepal-Russia Literary Association, argues that the twelve days of the Gufa ritual symbolize the twelve-month cycle of the sun and the subsequent seasons it brings (personal interview, 17 Mar 2015). Ancient people were certainly aware of the alterations in the sun's temperature and various seasons, which made them conclude that its rays could be harmful to young girls who had just hit puberty. Thus, the Gufa ritual became a traditional and celebratory means to shield their developing reproductive organs from the energy of the sun.

\section{Possibilities and Conclusion}

There are many cultural practices dealing with unique traditions and beliefs spread throughout the world. At a time when astronomy and space exploration is moving forward apace, it is also important to look back into our various cultural practices in which cosmic forces are both feared and revered. Hidden meanings in ancient cultures like Gufa can hold key information about the cosmos as perceived by people centuries ago. Even today, it is joyfully celebrated in Newar households of Nepal and abroad. Studies and research in cultural astronomy can reveal a plethora of information. The value of such practices needs to be respected and protected as global intangible heritage.

\section{References}

Allen, M. 1986, The Cult of Kumari (Kathmandu: Mandala Book Point)

Levy, R. 1990, Mesocosm: Hinduism and the Organization of a Traditional Newar City in Nepal (Berkeley: University of California Press)

Nepali, G. S. 2015, The Newars (Kathmandu: Mandala Book Point)

Tiwari, M. 2011, Women's Power to Heal: Through Inner Medicine (New York: Mother Om Media)

Van Gennep, A. 2011, The Rites of Passage (Chicago: University of Chicago Press) 